\title{
Markets and institutional swamps: tensions confronting entrepreneurs in developing countries
}

\author{
MATTHIAS OLTHAAR* \\ Stenden University of Applied Sciences, Van Schaikweg 94, Emmen 7811 KL, the Netherlands \\ WILFRED DOLFSMA** \\ Loughborough University London, Off Waterden Road, London E20 3BS, UK \\ CLEMENS LUTZ*** AND FLORIAN NOSELEIT**** \\ University of Groningen School of Economics and Business, PO Box 800, Groningen NL-9700 AV, the Netherlands
}

\begin{abstract}
Unrealized potential of entrepreneurial activities in developing countries has often been attributed to missing formal market-based institutions. In new institutional economics, the concept of 'voids' is suggested to describe the absence of market-based institutions. In reality, however, 'institutional fabrics' are always and necessarily complex and rich in institutions. No societal sphere is institutionally void. In this article, we contribute to existing literature on entrepreneurship and institutional economics by presenting a framework for studying the richness and complexities of institutional fabrics, as well as ways in which entrepreneurs respond to institutions. Distinguishing four types of institutions relevant for entrepreneurs, we analyze case study data from Ethiopia, and discuss how 'tensions' between potentially incompatible institutions result in behavioral frictions. Some entrepreneurs play the complex institutional environment and benefit from the tensions in it, whereas others may drown into the institutional 'swamp' they face. Policy makers should acknowledge that institutions not only result from formal policy making and that in many cases a diverse set of institutions is needed to facilitate market exchange and solve constraining tensions. The diversity that results from initiatives of institutional entrepreneurs may create a more effective institutional environment for development.
\end{abstract}

\section{Introduction}

Entrepreneurs are catalysts of economic development (Mair et al., 2012; Seelos and Mair, 2007), but, in developing countries in particular, their potential is

\footnotetext{
*Email: matthias.olthaar@stenden.com

**Email: w.a.dolfsma@lboro.ac.uk

***Email: c.h.m.lutz@rug.nl

****Email: f.noseleit@rug.nl
} 
not realized (Sutter et al., 2013). This stunted contribution of entrepreneurs to economic development is attributed by many to a weak institutional environment (Khanna and Palepu, 1997; 2000; Lee and Kim, 2009; Mair and Marti, 2009; Sutter et al., 2013). Institutions prescribing certain behaviors and dissuading other behavior (Neale, 1987) allow markets to function and firms to at least survive, if not to enjoy some measure of success (North, 1990; 1991). When institutions are absent, markets can be dysfunctional and many firms face a situation too uncertain to be successful. Small scale and entrepreneurial firms are particularly vulnerable in a weak institutional environment. McKague et al. (2016) discussed how in these environments an NGO may help to build the social structure of a viable new market. In this contribution, we focus on young existing markets in a context of institutional plurality and tensions (Mair et al., 2015; Oliver, 1991; for a general argument, see Dolfsma and Verburg, 2008).

Weakness of institutional environments is defined from a New Institutional Economics (NIE) point of view as a dearth of formal, market-based institutions (or their enforcement) (cf. North, 1990). Examples include weak (absent) contract law and property rights law. Whenever such institutions are not present, it is believed that markets operate in a void. Khanna and Palepu (1997) introduced the concept of institutional voids to describe such situations. The term 'institutional void' suggests emptiness, a vacuum that can relatively easily be filled (Mair et al., 2012). Adding formal, market-based institutions, ready-made from other jurisdictions, is then expected to stimulate economic development by supporting entrepreneurs.

In reality, however, as Original Institutional Economics (OIE) recognizes (Bush, 1987; Neale, 1987), neither entrepreneurs nor other actors in any practice in society ${ }^{1}$ face institutional voids, even for activities where no formal marketbased institutions exist in a country (jurisdiction). Instead, a rich and complex fabric of other, informal and non-market-based institutions affects them (cf. Mair et al., 2012). Informal institutions, or formal institutions that aim to regulate adjacent, non-market activities, will impinge on a practice for which no or a few formal institutions exist. Formal institutions regulating other practices may indirectly affect a focal practice, and informal institutions may directly or indirectly affect a focal practice as well. Any institutional fabric thus is rich and complex even when some formal institutions are lacking: no sphere is institutionally void. As institutions are developed or emerge to impinge on a different practice than intended, these may clash with others to produce tensions in a practice (Dolfsma and Verburg, 2008). A tension arises when different institutions impinge on the same focal practice yet prescribing behaviors that are inconsistent or even in conflict with each other. Tensions

1 A practice is ' . . . any form of activity specified by a system of rules [institutions] which defines offices, roles, moves, penalties, defences, and so on, and which gives activity its structure' (Rawls, 1955: 3). 
arise even when different formal institutions directly relevant for a focal practice prescribe different behaviors. An institutional fabric - the totality of institutions that actors face who are in a practice - that regulates a focal practice can be riddled with institutions that prescribe such diverse behaviors that the actors in it find themselves caught in what we call an institutional swamp, unable to act or constrained in developing behaviors they would otherwise prefer. Actors caught in an institutional swamp are likely to be less successful economically, for instance since they are vulnerable to unexpected enforcement actions. However, the swamp can also be seen as a challenge, to some actors, as it may give room for institutional entrepreneurship that changes the institutional fabric and forms the root for successful entrepreneurial activity.

Although previous research on institutions - especially in economics and political science - focuses on formal institutions, such an emphasis tends to ignore informal institutions, formal institutions primarily intended for other practices, as well as the possibility for all these institutions to interact with each other (Rakner and Randall, 2011: 60). We argue that the outcomes of institutional arrangements can only be understood when taking into account the dynamics of interaction between institutions, markets, and organizations (Djelic et al., 2005). Interactions between institutions may cause tensions perceived by actors in a focal practice. In this paper, we provide an analytical framework to understand the 'on-the-ground dynamics' and complexities (Mair et al., 2012: 819 ) in an institutional fabric that is not characterized by voids but by a possible institutional swamp. Analyzing all the different institutions impinging on a particular practice - entrepreneurial behavior in a well-defined and recognizable market setting - allows us to identify tensions resulting from contradicting prescriptions for behavior from diverse institutions, as well as heterogeneous responses to tensions. What opportunities and difficulties entrepreneurs face, what choices they make, and what chances of success they have is best understood when realizing that institutional spheres are always filled rather than void, but that behaviors prescribed can be in conflict.

We do so by presenting and analyzing empirical data on farmer organizations [cooperatives] in a developing country [Ethiopia], as here entrepreneurs are confronted with different types of institutions prescribing conflicting or contradicting behaviors. We submit that any practice, even the entrepreneurial activities of smallholders producing a highly homogenous agricultural commodity such as sesame seed in Humera, Ethiopia - a remote, barren corner of Africa - will have institutions that regulate the behavior of actors in it. We argue that this is an interesting setting for understanding an institutional swamp and the behavior of actors. The major reason for this is that the sesame market in Ethiopia is quite young and booming in the last decade. As in many developing and emerging markets, the institutional fabric that governs decisions of the actors involved is changing quickly and, therefore, provides an interesting context for our analysis. The case studies show that if the concept of institutional 
voids is adopted the on-the-ground-dynamics are insufficiently understood as too much attention is paid to missing formal market-based institutions, while the importance of tensions between these institutions and informal and indirect institutions is ignored. This also leads to the neglect of the role of individual actors and collective action to accommodate tensions between institutions. Sesame farmers in Ethiopia are much more diverse in terms of the resources they have at their disposal, approaches to farming and performance than one might expect (Olthaar, 2015). We find that both entrepreneurial failures and successes can better be understood and explained when studying the richness and complexities of the institutional environment of entrepreneurs, using the framework that we propose, than by means of studying only what the 'voids' are.

We proceed by first discussing relevant literature in Section 2, suggesting a conceptual framework. Section 3 elaborates on method and data, which are analyzed in terms of the framework presented in Section 4. We discuss our findings and provide conclusions in Section 5.

\section{Literature}

Institutions are society's devised rules, norms, values, or agreements that constrain certain behaviors in order to stimulate others (North, 1990; 1991). Alternatively, and more comprehensively, Hodgson (2006) defines institutions as systems of established and prevalent social rules that structure social interaction. Institutions give stability and predictability to the behaviors of individuals in a particular practice (Neale, 1987), but are also indispensable to understand change (Dolfsma and Verburg, 2008; Dolfsma et al., 2011). A social practice, at any aggregation level, country, industry, market, or organization, will be affected by a number of different institutions (Mair and Marti, 2009; North, 1990; Stein, 1994; 1991; Sutter et al., 2013).

Some claim that a lack of economic development and entrepreneurial failure is due to missing formal institutions, creating an institutional void (Castellacci, 2015; Khanna and Palepu, 1997; 2000; Mair and Marti, 2009). In reality, however, institutional fabrics are complex and rich in character, even when (some) formal institutions that regulate a practice elsewhere are lacking in a country under study. Not recognizing this deprives one of an explanation of complexities and 'on-the-ground dynamics' (Mair et al., 2012: 819) in a practice. What expectations of success players in a market have depends on the institutions they are facing.

\section{The institutional fabric (facing entrepreneurs): four types of institutions}

To analyze the institutions entrepreneurs are confronted with, and moreover competition between contradicting or conflicting institutions, we propose to distinguish between four types of (interrelated) institutions. Conceptually, our framework is aligned to Helmke and Levitsky's (2006) notion of competing 
or conflicting institutions, i.e., interactions between institutions that may cause dysfunctionality. In order to study such interrelations, it is beneficial to first identify the relevant institutional dimensions that allow identification of fabrics of interrelated institutions in which, as we argue below, a swamp can develop.

The first dimension that is relevant in our context is the differentiation between formal and informal institutions (Casson et al., 2010; Steer and Sen, 2010). Formal institutions comprise societies' 'constitutions, laws, [and] property rights' (North, 1991: 97). Formal institutions are codified, written down, and enforced by State bodies. Within countries formal institutions generally apply in the whole country and are equal for all the citizens. Informal institutions concern societies' 'sanctions, taboos, customs, traditions, codes of conduct', (North, 1991: 97) and 'religious beliefs' (Mair et al., 2012: 820). Informal institutions may differ between countries, groups, and even individual actors. Informal and formal institutions can have a variety of interrelations enhancing effectiveness (e.g., formal and informal institutions being complements and increasing their joint effectiveness, or informal institutions substituting non-functional formal institutions) or the opposite (e.g., formal and informal institutions competing with each other or being in an accommodating interrelationship) (cf. Helmke and Levitsky, 2004). That formal institutions do have an impact on entrepreneurship is realized widely among scholars, but informal institutions can also have a significant impact on the commercial chance of entrepreneurs (Dolfsma and De Lanoy, 2016).

Next to this differentiation, we argue that a second dimension is of crucial importance to understand the context in which institutional swamps may emerge, since competing and contradicting institutions may not only occur between formal and informal institutions but also among formal and among informal institutions themselves. In addition, while markets are a universal institution of exchange, institutions regulating behaviors of actors in markets are not only based on general grounds of market exchange (Rawls, 1995). Market exchange is embedded in a wider space of social exchange (Dolfsma et al., 2005). Market exchange also depends on institutions that do not primarily address market exchange, or are not intended or believed to do so. In other words, there are institutions directly targeting the practice of market exchange, while other institutions target other practices that may indirectly still affect markets. Therefore, we distinguish between institutions - formal as well as informal that directly target the market and those that influence behaviors and outcomes indirectly. Direct institutions are best described with existing definitions of economic institutions 'that define the production, allocation, and distribution process of goods and services, (Jütting, 2003: 14), comprising property rights, market mechanisms, contracts, money, and technology. Indirect institutions are those that do not primarily aim to influence production and allocation - but may indirectly do so (Rawls, 1955). Such indirect institutions are closest to the concept of nonmarket forces comprising 'social, political and legal arrangements 
Figure 1. Institutional fabric facing entrepreneurs.

\begin{tabular}{|c|c|c|}
\hline & Direct Effect & Indirect Effect \\
\hline Formal Institutions & $\begin{array}{l}\text { Contract laws } \\
\text { Property rights } \\
\text { Supporting apparatuses } \\
\text { Etc... }\end{array}$ & $\begin{array}{l}\text { Marriage law } \\
\text { Inheritance law } \\
\text { Environmental regulations } \\
\text { Etc... }\end{array}$ \\
\hline Informal Institutions & $\begin{array}{l}\text { Status as entrepreneur } \\
\text { Interest payment } \\
\text { Preferred business partner } \\
\text { Etc... }\end{array}$ & $\begin{array}{l}\text { Group culture } \\
\text { Group roles } \\
\text { Cultural beliefs } \\
\text { Etc... }\end{array}$ \\
\hline
\end{tabular}

that structure [...] interactions outside of, and in conjunction with, markets' (Baron, 1995: 48).

Conceptually then, we can derive four types of institutions (see Figure 1):

(1) Direct formal institutions;

(2) Direct informal institutions;

(3) Indirect formal institutions;

(4) Indirect informal institutions.

To make the abstract logic above more clear, consider the examples below that we derived from literature. First, concerning direct formal institutions, the abovementioned contract-law enforcement, protection of property rights, as well as established capital markets, and other supporting apparatuses serve as examples (Mair and Marti, 2009; North, 1990; 1991; Sutter et al., 2013). Second, an example of direct informal institutions may concern the status of an entrepreneur (Dolfsma and De Lanoy, 2016). Although in Western societies entrepreneurs may enjoy status, scholars found that in communist regimes and transition economies there were negative connotations to the term private enterprise or entrepreneurship. Entrepreneurs may lack status and respect (De Clercq et al., 2010). According to Aidis et al. (2008: 658) entrepreneurs in the Soviet Union were 'equated with "speculators" and often deemed criminals for making a profit'. Another example includes the acceptance of interest payment. Islamic banks do not permit contracts in which interests are paid or received (Ergec and Arslan, 2013), even if this is formally allowed. Furthermore, a recent study found that ethnicity plays an important role in selecting business partners (Hedge and Tumlinson, 2014). Third, concerning indirect formal institutions, one may think of a society's political system. Acemoglu and Robinson (2006) model how political institutions (including dictatorships, absolute monarchies, oligarchies, and corrupt or even populist democracies (p. 325)) affect economic institutions and outcomes. Furthermore, one may think of the ways in which marriage law and inheritance law (cf. Carney et al., 2014), or environmental regulations, may affect entrepreneurial behavior. Concerning the latter, Dean 
et al. (2009) found that a country's regulation concerning pollution is, under certain conditions, one of the factors affecting foreign direct investment decisions. Fourth, and at last, indirect informal institutions include examples of culture in general. Hawkins (1993) contrasts the individual character of entrepreneurship to the group (collective) orientation of Japanese culture. Individual acts of entrepreneurship go against accepted wisdom and are not valued in society. In other societies there are clear gender roles that prevent women from participating on the market. "Many societies continue to define women primarily through roles associated with family and household responsibilities. [...] Further, the entrepreneur's role is often characterized as being more masculine than feminine" (Baughn et al., 2006: 689). Bernard et al. (2010) argue that conservatism in African societies may prevent entrepreneurship. A major obstacle is that individual success is attributed to luck and not to effort. Since success is a consequence of luck, successful people are expected to share their success in the community. In addition if one is repeatedly more successful than others he or she can be thought to manipulate supernatural forces. Incentives to work hard are consequently reduced.

Figure 1 illustrates the four types of institutions in four different quadrants and where the above-mentioned examples fit. We refer to this figure as the institutional fabric. Although we use an idealized categorical distinction of institutions it is sometimes difficult to precisely delineate formal from informal or a direct from an indirect institution (cf. Helmke and Levitsky 2006). Indeed, we argue that the degree of formality or directedness should be rather understood as a continuum, whereas categorical representation eases clear representation.

\section{Tensions between institutions: institutional swamp}

The four types of institutions form the institutional fabric, a fabric that can be complex (Mair et al., 2012). We argue that this complexity results in large part from inconsistencies, conflict, or tensions between institutions (Dolfsma and Verburg, 2008). The concept of tensions forms a central part of the framework. We refer to a tension when actors in a certain practice are confronted with two or more institutions prescribing different kinds of behavior that cannot coexist. In such a situation, the actor will try to accommodate the tension by adhering more or less to a certain institution, while avoiding, and possibly ignoring, another institution (see also Dolfsma and Verburg, 2008; Neale, 1987; Oliver, 1991).

Tensions may exist between institutions within a cell in Figure 1 but also between institutions from different cells. For example, some formal direct institutions may stimulate market exchange while other institutions may result in high start-up or labor costs and, therefore, compromise market exchange (De Clercq et al., 2010; Duvanova, 2014; Estrin et al., 2013; Frederiksson, 2014; Hawkins, 1993). The former institutions (laws) are benefiting some parties in the market, whereas the latter institutions are benefitting others (cf. Dolfsma and McMaster, 2011; Heller, 2008). For the sake of simplicity, we do not 
elaborate on such intra-cell institutional tensions. Similarly, market exchange is generally based on institutions that make no gender differences; however, informal institutions may create tensions if gender issues, as indicated above, influence the market behavior of men and women differently.

We use the metaphor of a swamp since differences in prescribed behavior may make entrepreneurs be bogged down when they are not able to align the tensions. This is not to say that it is simply a matter of choice to the entrepreneurs whether or not they drown. It is merely to say that institutions may vary and so may the behavior and behavioral outcomes. What behavior to choose, what institution to adhere to, may not necessarily be obvious to individuals, hence, the tension. We stress that the concept of tension not only involves conflicting institutions prescribing different kinds of behavior that cannot coexist, but also includes the actual behavior. Institutions are ontologically different from behavior and the one cannot be reduced to the other (Dolfsma and Verburg, 2008).

\section{Tensions between institutions: institutional entrepreneurship}

Individual entrepreneurs are embedded in an institutional context but their behavior may also change this context (Seo and Creed, 2002). Several studies analyze institutional change processes and focus on the role of institutional entrepreneurs (DiMaggio, 1988; Dorado, 2005; Garud et al., 2002; Mair et al., 2015). Institutional entrepreneurs are actors who have an interest in modifying institutional fabrics and have sufficient tangible and intangible resources to do so (DiMaggio, 1988), either for all involved in a practice or to some.

Following the example on gender roles above, a woman in a certain society may choose not to become an entrepreneur because of informal institutions, she may decide to become an entrepreneur because law allows her to do so despite informal resistance, or she might invite others to front as entrepreneur for her and share the value created. Whichever behavior she chooses, in both cases she simultaneously adheres to certain institutions while avoiding yet possibly defying others (see also Oliver, 1991). Some market-related behaviors, or market-related behaviors by some, may conflict with formal or informal institutions in the society that do impact on market-related behavior, directly or indirectly. As a consequence of choices made by entrepreneurs, institutions and institutional fabrics may evolve. Continuing the example, this means that if women on a sufficiently large scale decide to start their own business, informal institutions that previously prevented them from doing so may change.

We follow Battilana et al. (2009: 72) in defining institutional entrepreneurs as 'agents who initiate, and actively participate in the implementation of, changes that diverge from existing institutions, independent of whether the initial intent was to change the institutional environment and whether the changes were successfully implemented'. Although we acknowledge that contradicting institutions may drown institutional entrepreneurs in the swamp it is also possible, in some circumstances and for some actors, that institutional 
entrepreneurs are able to change the institutional context and thereby sometimes actually benefit from the existing institutional tensions. It is even possible to see the tensions as a prerequisite or an enabling condition for institutional entrepreneurship (Seo and Creed, 2002). From this we derive two important observations. First, tensions are not necessarily counterproductive as they may provide room to some for institutional entrepreneurship. Second, the institutional environment is not fixed for individual entrepreneurial actors but can be moderated through their actions, at least at times. In particular, in young markets where the institutional environment is weakly developed or enforced, individual entrepreneurial action may affect the institutional context. Not enough is known about what allows institutional entrepreneurial actors to make institutions change.

We develop this framework of types of institutions each impinging on a practice, resulting institutional tensions, and a possible role for institutional entrepreneurial actors with case study data about farmer-entrepreneurs producing sesame in Ethiopia.

\section{Methodology}

A case study research design is the most appropriate for this study, since indepth, socially-complex, multi-level data is required for this study (Yin, 2004). Because of the demanding circumstances in the environment the study focused on, multiple sources of information have to be consulted. One goal of consulting a number of different sources of information is to exclude possible alternative explanations for the phenomenon investigated different from the one suggested (Yin, 2003). We have undertaken several rounds of data gathering, each time discussing with country and sector experts if the data we had gathered had to be supplemented by data from different sources. Consistency of insights generated, compared with insights the project had offered up to a particular point and compared with what the experts consulted were knowledgeable about, in particular, would trigger a quest for additional data in a subsequent round of data gathering. The institutional setting for cooperatives and their members has not been studied. In advance, it was unclear what variables would be relevant to include as possible control variables.

Dependent on a careful selection of the case or cases for a study, guided by considerations arising from the theory used and developed, case study research allows for generalization (e.g., Giddens, 1984). Cases that are similar, from the point of view of the theory adopted, should be expected to show the same findings when the method to do research is adopted in the exact same manner. Provided that this is the case, theoretical generalization to other contexts is not just possible but can be validly pursued. Ethiopia is a developing country, and Humera is a province inside Ethiopia, in which a particular kind of entrepreneurial activity (sesame farming) has only recently emerged as physically feasible. Institutions 
affecting this activity are developing, with a relative absence of formal, marketrelated institutions. This is a setting that should show the institutional void that some scholars discuss at length. Rather, as we find and as OIE would suggest, a number of different kinds of institutions, potentially in conflict with each other, impinge on the practice of entrepreneurship, presenting to the entrepreneurs a situation that many perceive as what we refer to as an institutional swamp. Entrepreneurs are curtailed in what they can feasibly do in their practice.

We collected case study data among cooperatives of sesame seed farmers in the Northwest of Ethiopia. The emphasis in our data collection was on both the institutional environment and the behavior of cooperatives. Cooperatives are expected to play a crucial role in the further development of agricultural markets in developing countries (World Bank, 2007). Most, but not all, farmers are seriously resource constrained and collective action is seen as an important instrument to provide them access to lacking resources (Bernard et al., 2010). Collective action may allow them to develop the resources needed to accommodate the tensions and to develop institutional entrepreneurship (DiMaggio, 1988, McKague et al., 2016). Interestingly, in this region, many cooperatives operate according to the same regulations, but have yet developed differently. Farmers can genuinely be conceived as entrepreneurs: individuals owning arable land can rent their land to others, taking a predetermined income and not accepting entrepreneurial risks for a deferred income. In addition, what resources farmer-entrepreneurs have differs between them and are actually being employed differently as well.

\section{Selection of the research site}

We were interested in collecting data in a developing country because institutional environments change quickly. In addition we wanted to be able to study how competing firms responded to institutional structures in this context. Ethiopia is chosen because the country is characterized by a high need to create institutions. The Northwest provided the scenery of severe fights during wars between the former regime and liberation fronts (until 1991) and between Ethiopia and Eritrea (around the year 2000). Formal direct institutions have been changing quickly as a result of the regime change and the economy has been growing at a fast pace since the beginning of the 21st century. In addition, sesame seed is a crop of major importance for the Ethiopian economy and therefore highly susceptible to policy making. After coffee it is the second largest source of export revenues. In the case of sesame seed farmers, institutions concerning the Ethiopia Commodity Exchange (ECX) and cooperative formation and management were designed and enforced. Production of sesame increased tenfold the past decade. Particularly in Northwest Ethiopia production increased rapidly and the quality of the sesame is considered to be high. After the war many farmers settled in the 'low-land' area Kafta-Humera that provides perfect 
conditions for cultivating the cash crop sesame: abandoned land is now used for the production of sesame. Increasingly farmers started cooperatives to benefit from sesame production and trade.

\section{Research process}

We collected secondary data on laws, proclamations, and principles concerning the formation of cooperatives and the trade in agricultural produce. Furthermore, a range of industry experts were interviewed in order to map the institutional environment. Once we came to understand the institutional environment we interviewed farmers and leaders of cooperatives to study how they respond to the institutional environment. In total, 131 interviews were conducted during six visits to Ethiopia (see the appendix). Qualitative data collection and analysis techniques were used as suggested by Eisenhardt $(1989 ; 1991)$ and Yin $(2003)$. In the initial exploratory phase of our data collection, we studied nine cooperatives as potential cases in our study. Below, we give more detail how we decided to include four of the nine cooperatives as exemplary cases to be included for further study. These cases allow us to draw out our findings while avoiding too much data in our article. The four cases each demonstrated distinguishing characteristics that the other five cases all exemplified as well (Eisenhardt and Graebner, 2007; Langley, 1999) - most cooperatives behaved in similar ways as the cooperative Adebay. Adebay therefore represents the majority of cooperatives. The other cooperatives, Humera 1, Humera 2, and Maikadra, are included because their behaviors differed despite the same institutional environment. These last three cases demonstrate how entrepreneurs can respond to tensions and how it affects performance.

In total we conducted 131 interviews. A complete break-down of interviewees is given in the appendix. The interviews served different purposes. The large number of interviews was necessitated by the fact that, though secondary data about the sesame sector in Ethiopia is available, it is limited and of poor quality. In addition, interviewing allowed for triangulation between primary and secondary data.

All interviews were semi-structured, face-to-face, and started by asking about a number of questions of a factual nature. Farmers, for instance, were asked about their farming and trading activities, household composition as well as how many hectares they farmed and how much of that was used for sesame. In total, nine interviews with members of cooperatives were conducted and seven with non-members. A well-educated translator who was familiar with agricultural practices in the region was involved in the collection of primary data. Industry experts were interviewed in order to come to understand the sector and its institutional environment. Industry experts are defined as 'highly knowledgeable informants who view the focal phenomena from diverse perspectives' (Eisenhardt and Graebner, 2007: 28). Industry experts included researchers from universities and research institutes, staff from various NGOs, 
aid workers, and consultants. Interviewing industry experts helped verify and complement data that we collected from interviews with farmers and cooperative representatives. Government staff at federal, regional (i.e., the region of Tigray) and local level (i.e., the county Kafta-Humera) was interviewed to come to understand their reasoning behind the development of policies, rules, and law and the way of enforcement. This was insightful, for example, since there appeared to be differences of opinion between federal and regional level on how to enforce certain laws. Other firms in the value chain not involved in production of sesame itself, ECX staff and spot market traders were interviewed to map the value chain, to study the farmers' positions in the value chain and to understand trade and supply conditions. These interviews revealed different outlets options available to farmers and cooperatives, and the conditions and advantages attached to each of them. Mapping the value chain allows for identifying entrepreneurial opportunities farmers can pursue, either individually or as a collective (i.e., at cooperative level). Large-scale farmers may have access to resources comparable to resources accessed by small-scale farmers who organize into a cooperative, but have a different governance structure and could therefore make decisions differently. Finally, leaders of cooperatives and farmers (both members of cooperatives and non-members) were interviewed. The interviews with senior managers of cooperatives (18 interviews in total) helped us to understand how entrepreneurial decisions are made at cooperative level.

This study is part of a larger research project focusing on other but related topics. We used the farm-level data collected by means of a survey among 369 farmers, 198 of whom were members of cooperatives, after conducting a pilot study involving 12 farmers, 7 of whom were members of cooperatives (Olthaar, 2015). We compared members of cooperatives to non-members in terms of their performance. In addition, to the extent that comparison is possible using this survey data, we found that institutional circumstances did not differ between members and non-members of cooperatives. Authors will provide this additional information upon request.

\section{Findings}

In this section, we first present and discuss institutions that farmer-entrepreneurs in the Kafta-Humera region of Ethiopia face, by category distinguished. Subsequently we show and analyze how institutions can conflict to create an institutional swamp for all but some entrepreneurs. The discussion in section 'Four types of institutions' gives the background for section 'Institutional tensions and entrepreneurial behavior', which provides the argument about why entrepreneurs in this context mostly find themselves in an institutional swamp, while some are able to navigate the tensions successfully. 


\section{Four types of institutions}

\section{Direct formal institutions}

Almost all sesame grown in Ethiopia is exported as raw, unprocessed sesame. Exporting firms are by law obliged to buy their sesame via the ECX. The ECX is an auction organizing wholesale transactions between buyers and sellers of several commodities. There are two exceptions to this rule: if cooperatives, their Union or Federation, export they can bypass the ECX and exporting firms that assume processing activities are allowed to engage in contract farming schemes with primary cooperatives.

According to direct formal institutions sesame seed farmers in Kafta-Humera have three sales outlets to choose from: (1) the cooperative, (2) the spot market trader, and (3) exporters via the ECX. Currently, most farmers sell to a spot market trader, whereas the remaining group of farmers sells to a cooperative. Small-scale farmers do not sell via the ECX for two major reasons. First, to sell via the ECX a license is required, which is too expensive for individual smallscale farmers. Second, a minimum of 50 quintals $^{2}$ has to be delivered. Small-scale farmers are not capable of delivering such quantities individually.

Cooperatives have not been in existence for long, as the former regime fell only in 1991. In 1997, the first new cooperatives started to emerge, but the civil war of 2000 interfered. Membership bases are now growing gradually, mostly due to increased recognition of the potential of collective action. According to law, cooperatives are organized at three levels: the region, the county (woreda), and the village (kebele). At kebele-level farmers are supposed to organize in so-called primary cooperatives. The primary cooperatives are expected to unite in a Union at the level of the woreda. The major role of the Union in this model, or the second-level cooperative, is to sell the farmers' produce in large quantities, for example, for exporting. The idea is that at the level of the Union required exporting capabilities can be developed such as language skills, legal skills, quality control, and quantity accumulation. In the region under study, Tigray, there is even a third-level cooperative called a Federation. Its distinctive functions are unclear as it assumes similar roles as the Union, albeit with a more diverse range of products and a larger scale. Primary cooperatives are by law allowed to export (supposed that they have the required resources), to sell to the Union, or to sell to exporters via the ECX. Similarly, the Union can export directly, sell to the Federation, or to exporting firms via the ECX.

Law further provides formal rules regarding the operations of cooperatives and prescribes that any group of farmers can start a cooperative in a kebele as long as the purpose of the cooperative differs from existing cooperatives. Members of a cooperative can determine the share price of the cooperative, though cooperatives should exist of at least 10 members and no member is

2 The local measuring standard of 1 quintal is 100 kilogram. 
allowed to have more than $10 \%$ of the shares. The law furthermore states that of the profit made $30 \%$ has to be put in a 'reserve fund' (although it is unclear what a reserve fund is), whereas $70 \%$ has to be distributed to members in the form of dividend. One member has one vote. Members can elect a leader for a period of three years which can be extended by one more period of three years. Only citizens of the village in which the cooperative is located are allowed to become member, although in case of shortage of money, a cooperative may accept members from another village.

A majority of farmers, however, chooses to sell their produce to spot market traders. Spot market traders bulk the produce of farmers and sell the sesame via the ECX. Traders are interesting for farmers as cooperatives are not operational permanently in all the kebeles. Moreover, traders pay cash, accept different qualities, buy frequently, and may even provide credit. Apparently, these advantages more than balance the alleged disadvantages concerning a weak bargaining position for farmers, the risk of cheating, and relatively low prices.

\section{Direct informal institutions}

In addition to institutions that are directly targeting sesame production and trade and are formally written down and enforced, there is a set of institutions that directly targets sesame production and trade, but are not formally codified. Remarkably, it is the government staff that ignores the formal institutions and intervenes to enforce informal ones. The government does so because it fears that without intervening the formal institutions cause farmers to be excluded from market participation and cooperative membership. Much of the staff (though not all of them) envisions a market in which every farmer can participate, preferably in one collective. The idea is that all-inclusiveness (including all farmers in one cooperative) will benefit the farmers (World Bank, 2007). As a result of this, staff from both federal and regional governments enforces certain informal institutions. A first institution is that, though formally allowed, government staff does not permit farmers to establish more than one cooperative per village. Government staff interferes in the formation of cooperatives and ensures that only so-called 'multi-purpose cooperatives' are formed with the effect that no other cooperative with a unique purpose can be formed anymore. To the Ethiopian government, cooperatives also are a means of controlling communities, and of suppressing politically unwelcome voices. Long sessions are conducted to ensure that the members of a cooperative democratically 'vote' to adopt a policy that the government favors for political reasons. Moreover, the government prevents direct export by primary cooperatives, even if they have capabilities to do so. Cooperatives are instructed that it requires a Union to benefit from export sales. Direct export by a cooperative would give additional resources to such a cooperative and would make it more difficult for the government to tax.

The situation on the ground is even more confusing as staff from the regional government of Tigray set up a Federation, a third-level cooperative, and uses 
its political powers to ensure that primary cooperatives supply sesame to the Federation rather than to the Union. It did so by engaging in long and repetitive meetings with leaders of cooperatives and by enforcing a new regulation that allowed primary cooperatives only to sell to the Union if they were able to proof the descent of their members. The latter is close to impossible in a region with a weak administration and so much illiteracy as in Kafta-Humera. The meetings functioned furthermore to 'convince' the leaders of cooperatives to buy fertilizer from the state-owned monopolist. Cooperatives are also pressured to keep the share price low to keep the cooperative accessible for new members and to provide benefits to the wider community, including non-members. Another salient aspect of the informal design is that leaders are supposed to receive a salary for every day worked independent of how much profit a cooperative makes.

Staff of the Regional Cooperative Agency (RCA) of Tigray explained that these meetings are 'a type of democratic approach. You cannot simply impose cooperatives and members to do something, but they need to be convinced of what they need to do by giving understanding'. They furthermore explained that because 'Ethiopia is a developing country the government functions to explain to leaders of cooperatives what the best thing is to do'.

At the level of the individual farmer there are also other important nongovernmental informal direct institutions regulating, for example, the provision of loans by spot market traders to farmers. Farmers engage in high pre-selling costs due to the need to rent a tractor for plowing, hire laborers for weeding and harvesting, buying bags for sesame, and other costs. Cooperatives often cannot provide such loans due to free riding of members in the past. As a consequence, cooperatives were defaulting on their loans provided by banks and government which are therefore currently unwilling to provide loans to the cooperatives. Access to loans from spot market traders is therefore highly attractive to farmers.

\section{Indirect formal institutions}

The number of indirect institutions relevant to sesame trade is smaller than the institutions mentioned so far. However, a very important one concerns access to land. All land is State-owned, but land can be leased from the State. Where most civilians can apply for the lease of two hectares, certain former fighters as a kind of retirement scheme received 10 hectares of land and 5,000 Ethiopian Birr (ETB) after the war. Some former fighters use this advantage to invest in sesame farming. The land distribution is also affected by inheritance laws. While land is leased for a certain period of time from the State, entitlements to land use can be inherited by children. A problem, however, is that when a farmer has two hectares and a number of children, the land is split-up and may become too small to make investments for cash crops in addition to food crops used for home consumption. A final formal, though indirect, institution concerns neighboring country Eritrea - which used to be part of Ethiopia - being an official enemy with 
Figure 2. Institutional fabric for farmers and cooperatives producing sesame in Ethiopia.

\begin{tabular}{|l|l|l|}
\multicolumn{2}{l}{ Direct Effect } & Indirect Effect \\
\cline { 2 - 3 } Formal Institutions & $\begin{array}{l}\text { ECX } \\
\text { Trade regulations } \\
\text { Cooperative formation } \\
\text { Cooperative governance }\end{array}$ & $\begin{array}{l}\text { Retirement scheme fighters } \\
\text { Inheritance law } \\
\text { State of war } \\
\text { Land-ownership }\end{array}$ \\
\cline { 2 - 3 } Informal Institutions & $\begin{array}{l}\text { Inclusiveness of membership } \\
\text { Role of the Federation } \\
\text { Loans of spot-market traders }\end{array}$ & $\begin{array}{l}\text { Gender roles } \\
\text { Religious beliefs } \\
\text { Status of former fighters }\end{array}$ \\
\hline
\end{tabular}

which Ethiopia is still at war (though there is hardly any fighting). Kafta-Humera borders Eritrea. Farmers are constrained by the war because it formally prevents cross-border trade.

\section{Indirect informal institutions}

Finally, concerning indirect informal institutions, perceived gender roles still determine leadership of cooperatives. People in rural Ethiopia do not accept female authority or leadership by a young person. This means that leaders are not elected based on competencies, but on gender and age instead. Though institutions on authority are not directly designed to address markets or firms, they do affect markets as well. Similarly, religion plays an important role. Recurrently farmers responded in interviews that only God can provide good harvests and that there is not much they can do themselves. This answer was also given on questions regarding opportunities for irrigation, use of chemicals, and farmer organization. In other words, religious institutions prescribe that God is controlling everything and that there is little that man can do to be successful. Finally, throughout the country soldiers that participated in liberating the country from the former regime enjoy much respect and status. This status is sometimes accompanied with certain privileges that may also affect markets.

\section{Institutional tensions and entrepreneurial behavior}

Figure 2 above empirically summarizes the institutional fabric that guides action of farmers and cooperatives as discussed above. Of particular theoretical interest are the resulting tensions and impact of these on entrepreneurial behaviors. After all, tensions and resulting entrepreneurial behaviors can make the institutional environment an institutional swamp to entrepreneurs. Drawing on the previous in 'four types of institutions' section, we discuss a number of tensions that entrepreneurs face. The point of departure is the view expressed in parts of the literature that the entrepreneurial practice is regulated by formal institutions that 
Figure 3. (Colour online) Institutional Tensions.

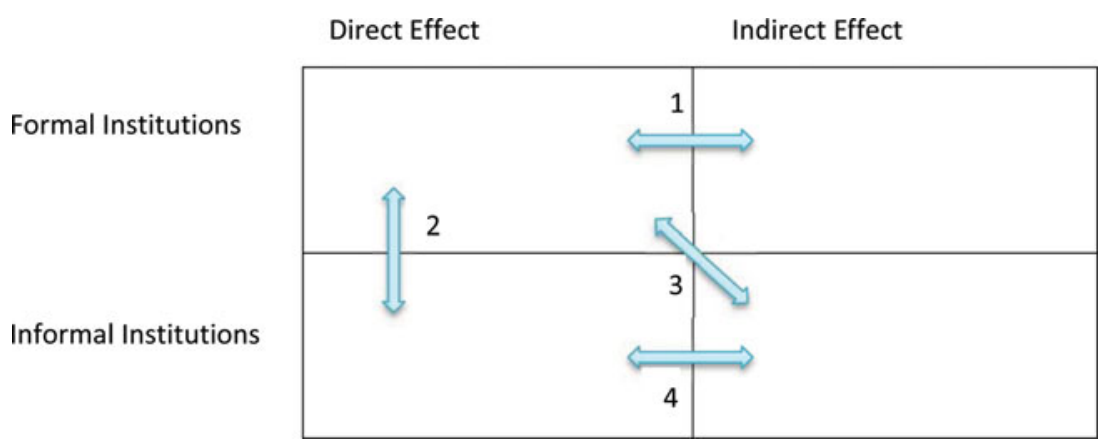

directly impinge on it. If these are not present, an institutional void is said to exist by some observers. This section makes the argument that the three other types of institutions also impinge on entrepreneurial activity, creating potential tensions of three kinds. Figure 3 indicates this situation. We discuss in this section in particular the possibilities that some actors have taken to seek to change the institutional environment to their own advantage.

Tensions of the first kind are present when formal institutions not primarily aimed at the focal practice of entrepreneurship by sesame seed farmers do affect this practice and lead to behaviors that actors would not otherwise show. Tensions of the second kind are present when formal institutions regulating the sesame market are not in line with how entrepreneurs themselves would organize the practice. Tensions of the third kind are present when informal institutions not primarily aimed at the focal practice do affect this practice and leads to behaviors that actors would not otherwise show. Tensions of the fourth kind, finally, are present when informal institutions not primarily directed at the focal practice of entrepreneurship (by sesame seed farmers in Ethiopia) actually do affect this practice and lead to behaviors that conflict with behaviors prescribed by informal institutions directly aimed at the focal practice.

Most salient tensions in the case of sesame seed cooperatives in Ethiopia come from conflicting direct formal and direct informal institutions (tension 2), but other tensions are real too. At times, it may not be unequivocally clear what kind of tension is at play. Where formally each group of at least ten farmers is allowed to start a cooperative, this is prevented through informal institutions that prescribe that each village may have only one cooperative dealing with a specific agricultural activity (tension 2). As the establishment of multi-purpose cooperatives is encouraged to exert more political control over villagers, there is not much room left for other agricultural cooperatives, which comes at the cost of specialization (tension 2). All land is owned by the State. After the civil war and the war with Eritrea formal laws were designed, based on egalitarian principles, to provide people the chance to get access to 2 hectares of land. However, 
former fighters received 10 hectares (tension 1). Economic reasons may pit against equally dividing land among farmers, yet these egalitarian principles were favored by the new regime after a long period of communist rule by the DERG regime (tension 1). At the same time, land or land rights cannot be sold. It can, however, be rented to others (tension 1 ). Leaders of cooperatives are formally allowed to determine the share price, but are informally pressured to keep the share price as low as 50 ETB (approximately 3 US Dollars; tension 2), such that the cooperative remains accessible to everyone. If everybody can become a member of a cooperative, the Ethiopian government is better able to exert influence over its citizens in this region. Cooperatives are furthermore formally allowed to determine how to reimburse the leaders and staff of the cooperative, but according to informal institutions the most preferred reimbursement is the 'per diem' salary in which leaders are paid for each day they have worked (tension 2). In addition cooperatives formally can choose to sell to different buyers (ECX, Union, importer, spot market trader), but are informally pressured to sell to the Federation (tension 2, and 3 as the tension is political as well). Solidarity principles prescribe the cooperative to bring benefits to the community and not just to its members only (tension 2) - tractors that the cooperative has purchased to help harvest and transport produce cannot be made available to members only or first. In other words, the cooperative is expected to consider the goods it creates more as social or local public goods than as club goods. Cultural, informal indirect institutions further prescribe that authority is a masculine role for senior people, but ignore needed competences (tension 3). Religious beliefs may cause farmers to refrain from making entrepreneurial investments in cooperatives, such as investments in irrigation (tension 3). Finally, the status of former fighters gives them rights that go against the informal direct institution of all-inclusiveness. Contrary to other farmers, former fighters are 'permitted' to form their own cooperative even if there is one already in a certain village (tension 4). These situations confront farmers and leaders of cooperatives with choices to make, exemplifying tensions of the kinds highlighted. Practices can differ slightly from one setting to the next, and actors within them can behave more or less as an institutional entrepreneur. We discuss the entrepreneurial practice in four villages in the Humera region in Ethiopia, where the villagecooperative of Adebay is representative for the most common behavior and the five village-cooperatives not discussed, and the other three cooperatives (Humera 1, Humera 2, and Maikadra) each show distinct features from the point of view of institutional entrepreneurial behavior.

\section{Adebay}

The cooperative Adebay is almost drowning in the swamp. Concerning the tensions above it often chose for institutions prescribing non-entrepreneurial behavior. The share price was kept low despite the organization's investments in a warehouse, office, and tractor. Leaders were paid per day, sitting in an office 
as much as possible rather than more directly for promoting the interests of the cooperative (tension 2). Leaders had little incentives to increase profits since this would not affect their salaries. The cooperative sold its supply to the Federation (tension 2 and 3), made its assets (such as the tractor) available on a first-comefirst-served basis (tension 2), and elected leaders based on seniority and gender (tension 3).

Several problems resulted that cause the cooperative to nearly drown. The elected, but incompetent, leader hardly enjoyed education and has little understanding of managing businesses. This makes him very susceptible to 'advices' from the RCA. We observed much dissatisfaction concerning the cooperative among both members and non-members. Members were about to lose their patience after not having received dividend for four to five consecutive years. Without dividend there is no price difference between what the cooperative pays to farmers and what spot market traders pay. Members started to lose their trust in the organization as they did not know what was done with the profits of the organization. The cooperative also did not have an accountant and was not transparent at all concerning revenues and costs. The leaders argued that the money was kept in the safe and that they were hoping for a government accountant to come (which had not come for over four years).

Aside from the lack of trust and incompetence of the leader, at the time, the cooperative could not trade in much sesame. The reason was that they were selling to the Federation. The Federation got into large financial problems and it took about four months before cooperatives received the money. In the meantime, cooperatives did not have money to finance other transactions. Cooperatives are not considered trustworthy lenders by banks and government, so borrowing money is not an option. The cash flow problems resulting from selling to the Federation limited the amount of sesame the cooperative could buy. The cooperative furthermore allowed new farmers to become member of the cooperative for only 50 ETB (tension 2). Though willingness to become member was low among non-members, the regulations also resulted in little willingness to invest among existing members (tension 2). In the past the cooperative used profits partially to buy equipment or to construct a warehouse. Non-members are given equal access to these assets as members, even though members forfeited the dividend the cooperative would have been able to pay had it not invested in these assets (tension 2). In the last interview, the leader said he would increase the share price to $100 \mathrm{ETB}$, but even if this is done, the share price would not reflect the value of the assets properly and, consequently, would not help to resolve the low willingness to invest.

\section{Humera 1}

That it is possible to play the institutional environment differently than Adebay, and all the cooperatives it represents are illustrated by three other cooperatives, of which the first one is Humera 1. The cooperative is fortunate to have a senior 
male leader who is educated and competent (tension 3). The leader of Humera 1 understood that for the cooperative to succeed it is vital to create trust among the members and willingness to invest. He therefore employed a certified accountant and created transparency by communicating clearly all the money streams. $\mathrm{He}$ decided not to have a per diem salary, but a commission based salary with which he would receive $2 \%$ of the profits made as reimbursement. As such he created an incentive to make as much profit as possible (tension 2). He wanted to engage in continuous buying and selling transactions, such that the limited cash available at the organization would realize a high turnover. This ambition was partially frustrated when he did not get paid quickly for the sesame he had sold to the Federation. This delayed payment made him threaten the Federation with a law suit. The threat alone was sufficient for the Federation to pay him quickly. The reason is that Humera 1 is one of the few cooperatives with an ECX license. The Federation is an initiative of the regional government, whereas the ECX is one originating from the federal government. The federal government has high stakes in making the ECX succeed and prefers cooperatives to sell via the ECX rather than to the regional Federation. The Tigray Federation feared its chances of success in a law suit at federal level. For a cooperative, selling via the ECX is interesting because buyers deposit money at the ECX prior to bidding and, therefore, sellers receive the money guaranteed within two days after sales (tension 2).

The leader of Humera 1 furthermore increased the share price to 400 ETB such that the share price would more closely reflect the organization's value (contrary to what was informally preferred by the RCA - tension 2). From the data we learn that members are highly positive about the organization, new farmers were joining, and revenues and profits have been increasing for a number of years. In addition, it paid dividends to its members.

We must stress that the actions taken by the leader of the cooperative are not simple choices. The pressures to conform to (in)formal institutions, including those indirectly affecting the entrepreneurship practice, are high. Staff of the RCA, for example, told us in an interview that they did not like this commissionbased salary and high share prices, and that they would take steps to inform the cooperative that these practices are not desirable. We do not know what steps the RCA effectively took, but up to the last interview the leader was sticking to his commission-based salary and share price. The pressures of the RCA, however, do make up the tension and make it less obvious for a leader what kind of reimbursement scheme to choose.

\section{Maikadra}

The third cooperative, Maikadra, is not drowning in the swamp, most importantly due to a processing firm interested in buying sesame directly from the cooperative (tension 2). The processing firm is organic certified and needs produce from certified farmers. However, at the ECX there is no grade or 
standard for organic produce. Sesame is bulked based on other criteria, making it impossible to buy organic produce via the ECX. The processing firm lobbied for over a year in order to be permitted to source sesame directly from Maikadra. As a result of this, the law recently changed and nowadays processing firms are allowed to source directly from cooperatives, thereby, bypassing the ECX. The government changed the law because it acknowledged the importance that more value-adding activities take place within its borders. The benefit for Maikadra is that in addition to a new sales outlet, it also gained access to organic fertilizer that the state-owned monopolist could not supply and loans provided by the processing firm.

The challenge for Maikadra is currently to remain supplier of the processing firm. They do make investments in warehouses and trucks, and only organic certified members can make use of it (tension 2), but the share price is still kept low despite these investments (tension 2). The access to loans (sesame farming requires high pre-selling costs), and organic fertilizer may be a sufficient reason for members to participate actively in the cooperative and new members to join, but more potential can be realized.

\section{Humera 2}

The name of this cooperative, Humera 2, already hints at a first tension that is challenged by its founders. Humera is the name of a village. According to informal institutions only one cooperative per village is permitted. The founders of Humera 2 found a way to play tension 1 and started their own cooperative with their own governance style, refusing new members, but enjoying high profits (tension 2). Humera 2 is an organization quite distinct from all the other cooperatives because it was not institutionalized according to the recommended blueprint. Humera 2 was founded in the year 2002 by 18 former fighters for the Tigray People's Liberation Front (TPLF). Their status provided them some extra freedom in playing the institutional environment (tension 4). The cooperative engaged in all kinds of activities including sesame farming and trade Their activities were diverse and the members were capable of engaging in diverse activities since they received 10 hectares of land after the war and 5,000 ETB (tension 1). Humera 2 formulated clear governance regulations. Its starting share price was 3,000 ETB, which is much higher than the conventional 50 ETB that other cooperatives charge. The members formulated strict agreements concerning commitment and tasks were distributed according to competencies. Profits would be invested immediately in new business activities and salaries would be equal for all members. If a member does not participate actively, he is sanctioned by means of not receiving a salary. No new members are allowed unless they know the potential member well (tension 2). Recently, they set the share price to 50,000 ETB. When data collection approached the end, Humera 2 even changed its legal status from a cooperative to a limited liability company. 


\section{Summary}

Above we discussed different tensions. The tensions confront the leaders of the cooperatives with choices to make. These choices affect their success. Most cooperatives, as represented by Adebay, face major problems and hardly survive. In other words, they are almost drowning in the swamp. Humera 1, Maikadra, and Humera 2 found ways to play the institutional environment and turn the tensions into opportunities to gain advantages. They used different mechanisms to do so. For the sesame seed cooperatives in our study, most tensions resulted from contradicting and conflicting direct formal and direct informal institutions.

\section{Discussion and conclusion}

No societal sphere, including a market, is an institutional void - even when no formal institutions directly seek to regulate actors' behavior in one sphere, informal institutions and formal institutions from another sphere will (Rawls, 1955). Rather than an institutional void, a plethora of possibly conflicting institutions, creating what we call here an 'institutional swamp', can hamper entrepreneurs. Institutional fabrics are complex we argue, and show that tensions that confront entrepreneurs arise. Attributing a lack of entrepreneurial behavior to the absence of direct formal institutions (or their enforcement), to 'voids', may be misleading. Voids ignore the 'on the ground dynamics' (Mair et al., 2012: 819), and the interactions between institutions. We propose a framework to understand these dynamics, allowing for a better sense of what affects entrepreneurs.

In remote, barren Humera, a region in Ethiopia where a few formal institutions exist in direct support of entrepreneurship and market exchange, informal institutions and formal institutions from others spheres impinge. From such other spheres, an important example is the principle of solidarity that conditions the market and the informal blueprint that local government staff recommends. A consequence is that each municipality is officiously only permitted to have one cooperative. In addition, partly informally, no farmer can be excluded from a collective, despite resulting free-riding problems.

When some institutions - formal or informal, directly aimed at a sphere or not - prescribe one kind of behavior, and other institutions prescribe different, conflicting behaviors, ambiguity and tensions arise. Some actors are able to play the environment and act more entrepreneurially, whereas others are paralyzed and risk 'drowning in the institutional swamp'. Institutional entrepreneurs make choices that avoid the tensions that arise from conflicting institutional prescriptions for behavior. Institutional contexts do allow for agency. Institutional entrepreneurs do not simply ignore institutions that prevent them from adopting preferred behaviors in pursuit of their goals. Rather, they can reach their goals by adopting behaviors that are, for instance, ostensibly 
in line with institutions that could be seen to hamper reaching a goal. Humera 1 , for instance, is strongly focused on market transactions and the pursuit of profits, in apparent contrast with principles of solidarity, but can do so as it also invests in the community. In addition, it can resist regional government pressures to supply the Federation by drawing on its cognitive and financial resources and threatening with a law suit. These actions are legitimate, but only successful if properly played.

Cooperative leaders should have resources, but should in particular be seen as legitimately behaving themselves (cf. Oliver, 1991). Members of Humera 2 have a strong reputation having served for a long time as officers in the army against the former regime. If the leader of a cooperative is chosen because of seniority, rather than merit, however, chances that he can effectively act as an institutional entrepreneur avoiding an institutional swamp may be lower.

The room for some to play the institutional environment, but also the difficulty for many to do so, has hardly been recognized in studies on institutional environments and entrepreneurship in developing countries. Recognizing this room is of importance to current literature as it maps the space in which (institutional) entrepreneurs can maneuver, avoid drowning in an institutional swamp, and be successful. Humera 1, Humera 2, and Maikadra mostly adhered to market institutions, each in their own way, whereas the other cooperatives, represented by Adebay, mostly adhered to institutions far less friendly to market exchange. As a consequence, the prime goal of having a cooperative, seeking scale economies to strengthen the position in the market, cannot be reached.

The framework we propose allows one to understand the 'on the ground dynamics' in a sphere in society. Informal institutions and formal institutions, direct, or indirect, can prescribe behaviors. The behaviors prescribed can conflict, causing tensions in a sphere, and giving rise to what we call an institutional swamp. Institutional entrepreneurs, skilled and possessing legitimate resources that they employ in a way that is seen as legitimate, can resolve some of the conflicts and indicate worthwhile solutions for further economic development. Successful cooperatives that play the institutional environment can become inspiring benchmarks for others.

In conclusion, we argue that not only unrealized potential of entrepreneurial activity in developing countries can be attributed to institutional environments, but so can realized potential. The crux is not just to study what is absent, the voids, but more so what is present. The richness of societies' institutional fabrics explains to a greater extent entrepreneurial activity than do so-called voids. Mair et al. (2012) already made this argument, but to date no framework for studying institutional fabrics has been developed or used in the literature. We argue that the framework that we propose in the current article, as well as the conceptualization of the institutional swamp, increases the rigor of studies on institutional environments and entrepreneurial activity in developing countries. 


\section{Managerial and policy implications}

Perceiving a societal sphere as an institutional void in case there are no or a few formal institutions that directly prescribe behaviors in it, naively ignores the fact that informal institutions, as well as formal institutions that are primarily focused on a different sphere, do impinge on it too (cf. North, 1990). Ignoring that will give rise to the naive policy suggestion to import formal institutions that elsewhere regulate such a sphere. For policy makers, an important implication is to find the balance in institutional fabrics that satisfies the principles that a society values, yet reduces ambiguity. In other words, institutions targeting the practice of market exchange need to be aligned with institutions targeting other values, preferably in such a way that society's values are hardly compromised. Furthermore, the importance of legitimacy is important to recognize. Top-down designed and installed institutions may not bear legitimacy in society and evoke acts of defiance, avoidance, resistance, or other acts of agency (see Oliver, 1991). Moreover, policy makers should facilitate institutional entrepreneurs as they may be helpful in finding the proper balance and in creating more effective institutions.

For cooperatives and involved NGOs, an important implication from our study is to detect the room for maneuvering, the room existent in institutional fabrics to play the environment. Particularly in the context of ambiguity, varied acts of behavior may be possible. In other words, institutional entrepreneurship can be a source of competitive advantage in such settings. Similarly, NGOs supporting firms in developing countries can benefit from recognizing the complexities of institutional fabrics, and to exploit tensions in the benefit of supported firms.

\section{References}

Acemoglu, D. and J. A. Robinson (2006), 'De Facto Political Power and Institutional Persistence', American Economic Review, 96(2): 325-330.

Aidis, R., S. Estrin, and T. Mickiwicz (2008), 'Institutions and Entrepreneurship Development in Russia: A Comparative Perspective', Journal of Business Venturing, 23(6): 656-667.

Baron, D. P. (1995), 'Integrated Strategy: Market and Nonmarket Components', California Management Review, 37(2): 47-65.

Battilana, J., B. Leca, and E. Boxenbaum (2009), 'How Actors Change Institutions: Towards a Theory of Institutional Entrepreneurship', Academy of Management Annals, 3(1): 65-107.

Baughn, C. C., B.-L. Chua, and K. E. Neupert (2006), 'The Normative Context for Women's Participation in Entrepreneurship: A Multicountry Study', Entrepreneurship Theory \& Practice, 30(5): 687-708.

Bernard, T., A. De Janvry, and E. Sadoulet (2010), 'When Does Community Conservatism Constrain Village Organizations?', Economic Development and Cultural Change, 58(4): 609-641.

Bush, P. D. (1987), 'The Theory of Institutional Change', Journal of Economic Issues 21(3): 1075-1116. 
Carney, M., E. Gedajlovic, and V. M. Strike (2014), 'Dead Money: Inheritance Law and the Longevity of Family Firms', Entrepreneurship Theory and Practice, 38(6): 1261-1283.

Casson, M. C., M. Giusta, and U. S. Kambhampati (2010), 'Formal and Informal Institutions and Development', World Development, 38(2): 137-141.

Castellacci, F. (2015), 'Institutional Voids or Organizational Resilience? Business Groups, Innovation, and Market Development in Latin America', World Development, 70(c): 43-58.

Dean, J. M., M. E. Lovely, and H. Wang (2009), 'Are Foreign Investors Attracted to Weak Environmental Regulations? Evaluating the Evidence from China', Journal of Development Economics, 90(1): 1-13.

De Clercq, D., W. M. Danis, and M. Dakhli (2010), 'The Moderating Effects of Institutional Context on the Relationship Between Associational Activity and New Business Activity in Emerging Economies', International Business Review, 19(1): 85-101.

DiMaggio, P. J. (1988), 'Interest and Agency in Institutional Theory', in L. Zucker (ed.), Institutional Patterns and Organizations. Cambridge, MA: Ballinger.

Djelic, M.-L., B. Nooteboom, and R. Whitley (2005), 'Introduction: Dynamics of Interaction between Institutions, Markets and Organizations', Organization Studies, 26(12): 17331741.

Dolfsma, W. and F. De Lanoy (2016), 'Outside vs. Inside Entrepreneurs: When Institutions Bind and Favors Blind', Journal of Economic Issues 50(2): 382-389.

Dolfsma, W., J. Finch, and R. McMaster (2005), 'Market and Society: How do they Relate, and How do they Contribute to Welfare?', Journal of Economic Issues 39(2): 347-356.

Dolfsma, W., J. Finch, and R. McMaster (2011), 'Identifying Institutional Vulnerability: The Importance of Language, and System Boundaries', Journal of Economic Issues 45(4): $805-818$.

Dolfsma, W. and R. McMaster (2011), 'Policy Conflict: Market-Oriented Reform in Health Care', Journal of Economic Issues 45(2): 309-316.

Dolfsma, W. and R. Verburg (2008), 'Structure, Agency, and the Role of Values in Processes of Institutional Change', Journal of Economic Issues, 42(4): 1031-1054.

Dorado, S. (2005), 'Institutional Entrepreneurship, Partaking, and Convening', Organization Studies, 26(3): 385-414.

Duvanova, D. (2014), 'Economic Regulations, Red Tape, and Bureaucratic Corruption in Post-Communist Economies', World Development, 59(c): 298-312.

Eisenhardt, K. M. (1989), 'Building Theories from Case Study Research', Academy of Management Review, 14(4): 532-550.

Eisenhardt, K. M. (1991), 'Better Stories and Better Constructs: The Case for Rigor and Comparative Logic', Academy of Management Review, 16(3): 620-627.

Eisenhardt, K. M. and M. E. Graebner (2007), 'Theory Building From Cases: Opportunities and Challenges', Academy of Management Journal, 50(1): 25-32.

Ergec, E. H. and B. G. Arslan (2013), 'Impact of Interest Rates on Islamic and Conventional Banks: the Case of Turkey', Applied Economics, 45(17): 2381-2388.

Estrin, S., J. Korosteleva, and T. Mickiewicz (2013), 'Which Institutions Encourage Entrepreneurial Growth Aspirations?', Journal of Business Venturing, 28(4): 564-580.

Frederiksson, A. (2014), 'Bureaucracy Intermediaries, Corruption and Red Tape', Journal of Development Economics, 108(c): 256-273.

Garud, R., S. Jain, and A. Kumaraswamy (2002), 'Institutional Entrepreneurship in the Sponsorship of Common Technological Standards: The Case of Sun Microsystems and Java', Academy of Management Journal, 45(1): 196-214. 
Giddens, A. (1984), The Constitution of Society: Outline of the Theory of Structuration, University of California Press.

Hawkins, D. I. (1993), 'New Business Entrepreneurship in the Japanese Economy', Journal of Business Venturing, 8: 137-150.

Hedge, D. and J. Tumlinson (2014), 'Does Social Proximity Enhance Business Partnerships? Theory and Evidence from Ethnicity's Role in US Venture Capital', Management Science, 60(9): 2355-2380.

Heller, M. (2008), The Gridlock Economy: How Too Much Ownership Wrecks Markets, Stops Innovation, and Costs Lives. Basic Books.

Helmke, G. and S. Levitsky (2004), 'Informal Institutions and Comparative Politics: A Research Agenda', Perspectives on Politics, 2(4): 725-740.

Helmke, G. and S. Levitsky (2006), Informal Institutions and Democracy: Lessons from Latin America, Baltimore: Johns Hopkins University Press.

Hodgson, G. M. (2006), 'What are Institutions?', Journal of Economic Issues, 41(1): $1-25$.

Jütting, J. (2003), 'Institutions and Development: A Critical Review', OECD Development Centre Working Paper No. 210.

Khanna, T. and K. Palepu (1997), 'Why Focused Strategies May be Wrong for Emerging Markets', Harvard Business Review, 75(4): 41-51.

Khanna, T. and K. Palepu (2000), 'The Future of Business Groups in Emerging Markets: Long-Run Evidence from Chile', Academy of Management Journal, 43(3): 268285.

Langley, A. (1999), 'Strategies for Theorizing from Process Data', Academy of Management Review, 24(4): 691-710.

Lee, K. and B.-Y. Kim (2009), 'Both Institutions and Policies Matter but Differently for Different Income Groups of Countries: Determinants of Long-Run Economic Growth Revisited', World Development, 37(3), 533-549.

Mair, J. and I. Marti (2009), 'Entrepreneurship in and Around Institutional Voids: A Case Study from Bangladesh', Journal of Business Venturing, 24(5): 419-435.

Mair, J., I. Marti, and M. J. Ventresc (2012), 'Building Inclusive Markets in Rural Bangladesh: How Intermediaries Work Institutional Voids', Academy of Management Journal, 55(4): 819-850.

Mair, J., J. Mayer, and E. Lutz (2015), 'Navigating Institutional Plurality: Organizational Governance in Hybrid Organizations', Organization Studies, 36(6): 713-739.

McKague, K., C. Zietsma, and C. Oliver (2016), 'Building the Social Structure of a Market', Organization Studies, 37(8): 709-733.

Neale, W. C. (1987), 'Institutions', Journal of Economic Issues 21(3): 1177-1206.

North, D. C. (1990), Institutions, Institutional Change, and Economic Performance, Cambridge, UK: Cambridge University Press.

North, D. C. (1991), 'Institutions', Journal of Economic Perspectives, 5(1): 97-112.

Oliver, C. (1991), 'Strategic Responses to Institutional Processes', Academy of Management Review, 16(1): 145-179.

Olthaar, M. (2015), Cultivating Sources of Competitive Advantage - Opportunities for SmallScale African Farmers in Global Value Chains, Groningen: Ispkamp.

Rakner, L. and V. Randall (2011), 'Institutional Perspectives', in P. Burnell, V. Randall, and L. Rakner (eds.), Politics in the Developing World, 3rd ed., New York: Oxford University Press.

Rawls, J. (1955), ‘Two Concepts of Rules', The Philosophical Review, 64(1): 3-32. 
Seelos, C. and J. Mair (2007), 'Profitable Business Models and Market Creation in the Context of Deep Poverty: A Strategic View', Academy of Management Perspectives, 24(4): 4963.

Seo, M. G. and W. E. D. Creed (2002), 'Institutional Contradictions, Praxis, and Institutional Change: A Dialectical Perspective', Academy of Management Perspective, 27(2): 222247.

Steer, L. and K. Sen (2010), 'Formal and Informal Institutions in a Transition Economy: The Case of Vietam', World Development, 38(11): 1603-1615.

Stein, H. (1994), 'Theories of Institutions and Economic Reform in Africa', World Development, 22(12): 1833-1849.

Sutter, C. J., J. W. Webb, G. M. Kistruck, and A. V. G. Bailey (2013), 'Entrepreneurs' Responses to Semi-Formal Illegitimate Institutional Arrangements', Journal of Business Venturing, 28(6): 743-758.

World Bank (2007), World Development Report 2008. Agriculture for Development, Washington: The International Bank for Reconstruction and Development/The World Bank.

Yin, R. K. (2003), Case Study Research, Thousand Oaks, CA: Sage Publications, Inc.

\section{Appendix}

\begin{tabular}{lr}
\hline We conducted the following number interviews & \\
\hline Cooperatives (leaders and staff) & 3 \\
Humera 1 & 2 \\
Humera 2 & 3 \\
Maikadra & 3 \\
Adebay & 1 \\
Central & 1 \\
Aydola & 2 \\
Bereket & 2 \\
Baekar & 1 \\
Tirkan & \\
Other farmer organizations & 1 \\
Large-scale farmers' cooperative & 3 \\
Sesame farmers' union Humera & 2 \\
Sesame farmers' union Sanja & 2 \\
Oromiya Coffee Union & 3 \\
Federation & \\
Farmers & 9 \\
Members of cooperatives & 7 \\
Non-members & 11 \\
Large-scale farmers & \\
Other & 16 \\
Government staff & 32 \\
Industry experts & 20 \\
Export and processing firms & 4 \\
ECX staff & 3 \\
Spot market traders & \\
\hline \hline &
\end{tabular}

